\title{
How an Infectious Disease Could Influence the Development of a Region: The Evidence of the SARS-CoV-2 Outbreak over the Tourism Intentions in Azores Archipelago
}

\author{
Bulaşıcı Hastalıklar Bölgesel Kalkınmayı Nasıl Etkiler: Azor Adaları'nda SARS-CoV-2 Salgınının \\ Turizm Sektörüne Etkileri
}

\author{
Rui Alexandre CASTANHO ${ }^{1,2,3,4,5}$ \\ (D) 0000-0003-1882-4801 \\ Gualter COUTO ${ }^{1}$ \\ (D) 0000-0001-5560-5101 \\ Pedro PIMENTEL ${ }^{1}$ \\ (D) 0000-0003-1056-0338 \\ Áurea SOUSA ${ }^{6}$ \\ (D) 0000-0003-3151-5237 \\ Célia CARVALHO ${ }^{7,8}$ \\ (D) 0000-0003-4453-8139 \\ Maria da Graça BATISTA ${ }^{\mathbf{1}}$ \\ (D) 0000-0002-0832-0397
}

${ }^{1}$ University of Azores School of Business and Economics and CEEAplA, Ponta Delgada, Portugal ${ }^{2}$ WSB University in Dąbrowa Górnicza Faculty of Applied Sciences Dąbrowa Górnicza, Poland

${ }^{3}$ VALORIZA-Research Centre for Endogenous Resource Valorization, Portalegre, Portugal

${ }^{4}$ CITUR-Madeira-Centre for Tourism Research, Development and Innovation, Funchal-Madeira, Portugal ${ }^{5}$ Aquageo Ambiente Legal-University of Campinas, Brazil (UNICAMP), Campinas, Brazil

${ }^{6}$ University of Azores Faculty of Sciences and Technology and CEEAplA, Ponta Delgada, Portugal

${ }^{7}$ University of Azores Faculty of Social and Human Sciences, Ponta Delgada, Portugal

${ }^{8}$ University of Coimbra Faculty of Psychology and Educational Sciences CINEICC-Cognitive and Behavioral Centre for Research and Intervention, Coimbra, Portugal

\section{Corresponding Author} Sorumlu Yazar

Rui Alexandre CASTANHO

acastanho@wsb.edu.pl

Received / Geliş Tarihi : 08.01.2021 Accepted / Kabul Tarihi : 21.03.2021 Available Online /

Çevrimiçi Yayın Tarihi : 25.03.2021

\begin{abstract}
Aim: After a contagious disease outbreak, as is the case of severe acute respiratory syndrome coronavirus 2 (SARS-CoV-2), societal dynamics shift on an unconventional level. In the lack of a vaccine, social distancing and massive lockdowns are acquired as the most effective strategies to contain this new virus. In this regard, the present study was carried out to determine the influence of SARS-CoV-2 over the Azores territory activities as tourism and consequent regional development impacts.

Material and Methods: Therefore, the study assessed the decision-makers, the public, and tourists' perceptions regarding this disease outbreak by applying testing tools as questionnaires. This study used a sample of 700 participants. The questionnaires were designed, considering the necessity to carry out online interviews, and were implemented in the Spring months of 2020. After the data from the surveys were gathered, analytical methods and tools were used. Results: The research recognized that during an infectious disease outbreak, people prioritized spending their vacations at the holiday residence of family or friends (20\%) instead of touristic resorts (hotels or rented apartments or houses). Also, the study verified a considerable increase in selecting rural tourism accommodations. Besides, more than half of the study participants considered that the "Clean and Safe" stamp (attributed by the Portuguese Health Authorities) is crucial when choosing accommodation and restaurants (75.8\%) as well as for choosing the destination to visit $(50.5 \%)$.

Conclusion: The study assumes enormous consequences of the SARS-CoV-2 crisis at multilevels, being the tourism activity the most affected in this ultra-peripheral region.

Keywords: Azores archipelago; regional studies; SARS-CoV-2; sustainable planning; territorial impacts.

\section{öz}

Amaç: Şiddetli akut solunum yolu sendromu koronavirüsü 2 (severe acute respiratory syndrome coronavirus 2, SARS-CoV-2)'nin yol açtığı bulaşıcı hastalık sosyal hayat1 alışılagelmedik bir şekilde etkilemiştir. Aşılamaya kadar, bu yeni virüsü kontrol altına almak için sosyal mesafe ve kitlesel kısıtlamalar en etkili stratejiler olarak ortaya çıkmaktadır. Bu çerçevede, bu çalışma SARS-CoV-2'nin Azores bölgesi turizm sektörü faaliyetleri üzerindeki etkilerinin ve bölgesel kalkınmaya yansımalarının incelenmesi amacıyla yürütülmüştür.

Gereç ve Yöntemler: Bu nedenle bu çalışmada, anket yöntemi uygulanarak karar alıcıların, kamunun ve turistlerin gözünden bu salgının algısı değerlendirildi. Çalışmanın örneklemi 700 katılımcıdan olușmaktadır. Anketler, çevrimiçi görüșme yapma gerekliliği göz önünde bulundurularak tasarlanmış ve 2020 yılının ilkbahar aylarında uygulanmıştır. Anketlerden elde edilen veriler toplandıktan sonra analitik yöntemler ve araçlar ile değerlendirilmiştir.

Bulgular: Araştırma sonuçlarına göre bu bulaşıcı hastalık salgını döneminde bireyler tatil tercihlerini turistik tatil tesisleri (oteller veya daire ya da ev kiralamak)'nden ziyade öncelikli olarak aile veya arkadaşlarının tatil evinde geçirme (\%20) doğrultusunda yapmışlardır. Ayrıca, tatil tercihlerinde kırsal kesim turizm konaklama yerlerinin seçiminde de önemli artışlar olduğu gözlenmiştir. Bunun yanında, araştırmaya katılan bireylerin yarısından fazlası konaklama ve restoran seçiminde $(\% 75,8)$, ve ziyaret edilecek olan destinasyonların seçiminde $(\% 50,5)$ Portekiz Sağlık Kurulları tarafından tescillenen "Temiz ve Güvenli" pulunun bulunmasının çok önemli olduğunu düşünmekteydi.

Sonuç: Bu çalışma, SARS-CoV-2 dolayısıyla ortaya çıkan olumsuzlukların birçok katmanda ağır etkilerinin varlığını, özellikle bu çok periferdeki bölgede turizmin en fazla etkilenen sektör olduğunu ortaya koymuştur.

Anahtar kelimeler: Azores archipelago; bölgesel çalışmalar; SARS-CoV-2; sürdürülebilir planlama; bölgesel etkiler. 


\section{INTRODUCTION}

The disease induced by the new coronavirus (severe acute respiratory syndrome coronavirus 2, SARS-CoV-2), emerging in Wuhan's city (China), spread rapidly worldwide in just a few months, affecting almost every region on the planet $(1,2)$. The high degree of contagion was achieved due to the considerable flow of public transport and human contacts. Therefore, we are facing a health catastrophe (1). In fact, several previous studies prove the fundamental role of air travel in increasing the spread of infectious diseases, such as the case of the SARS-CoV-2 (3-5). According to scholars as Burkle (6), "...the relationship between pandemics and travel is essential to understand public health security...".

In the lack of a vaccine, social distancing and massive lockdowns are acquired as the most effective strategies to contain this new virus. Despite this, such measures are associated with several obstacles, especially for economies inextricably linked to the production and sale of goods or tourism. In this sense, several authors have warned of the possibility of a health crisis shaking society and tourism on a large scale (7-16).

The current state of social, economic, and health dilemmas in which we live seems to point effectively to the scenario described above (17-18), witnessing fundamental changes in many activities - i.e., the tourism industry (19-24).

In this regard, businesses and individuals' economic conditions are deteriorated, particularly in the areas most exposed to the health crisis's immediate impacts, as is the case of the tourism field. Thereby, this crisis's financial long-term impact will considerably depend on the answers proffered from a multidisciplinary perspective.
So, if we focus on the ultra-peripheral territories, as is the case of the Autonomous Region of the Azores, this virus outbreak could represent even more impacts - once in those activities as tourism plays a central role in its socioeconomic sphere (25-27). Thereby, the current research intended to answer the following research problem: "How can an infectious disease influence the development of an ultra-peripheral region as the Azores?".

Consequently, this study seeks to identify and evaluate the consequences of SARS-CoV-2 over the Azores Region, specifically through the analysis of main-actors, the public, and the tourists' perceptions. So, it is expected to contribute to the thematic literature.

\section{The Azores Region in Brief}

The Azores Archipelago belongs to the Macaronesia Region (Figure 1). Madeira, Cape Verde, and the Canary Islands are also included in this region located in the North Atlantic. The Archipelago has nine islands and a total surface area of around $2,322 \mathrm{~km}^{2}$, corresponding to approximately $2.5 \%$ of the Portuguese national territory $\left(92,256 \mathrm{~km}^{2}\right)$. The islands are grouped by geographical proximity in 3 groups:

(i) Eastern; (ii) Central; (iii) and Western.

The three biggest islands are São Miguel, Pico, and Terceira - and they represent approximately $68.5 \%$ of the total area and about $85 \%$ of the Azores population. Population densities per $\mathrm{km} 2$ fluctuate between 184 inhabitants on the biggest island and 27 inhabitants on the smallest island. Amongst the 19 municipalities in the Azores, the largest is Ponta Delgada's isle of São Miguel. Contrarily, the smallest is Vila do Corvo on Corvo's island,

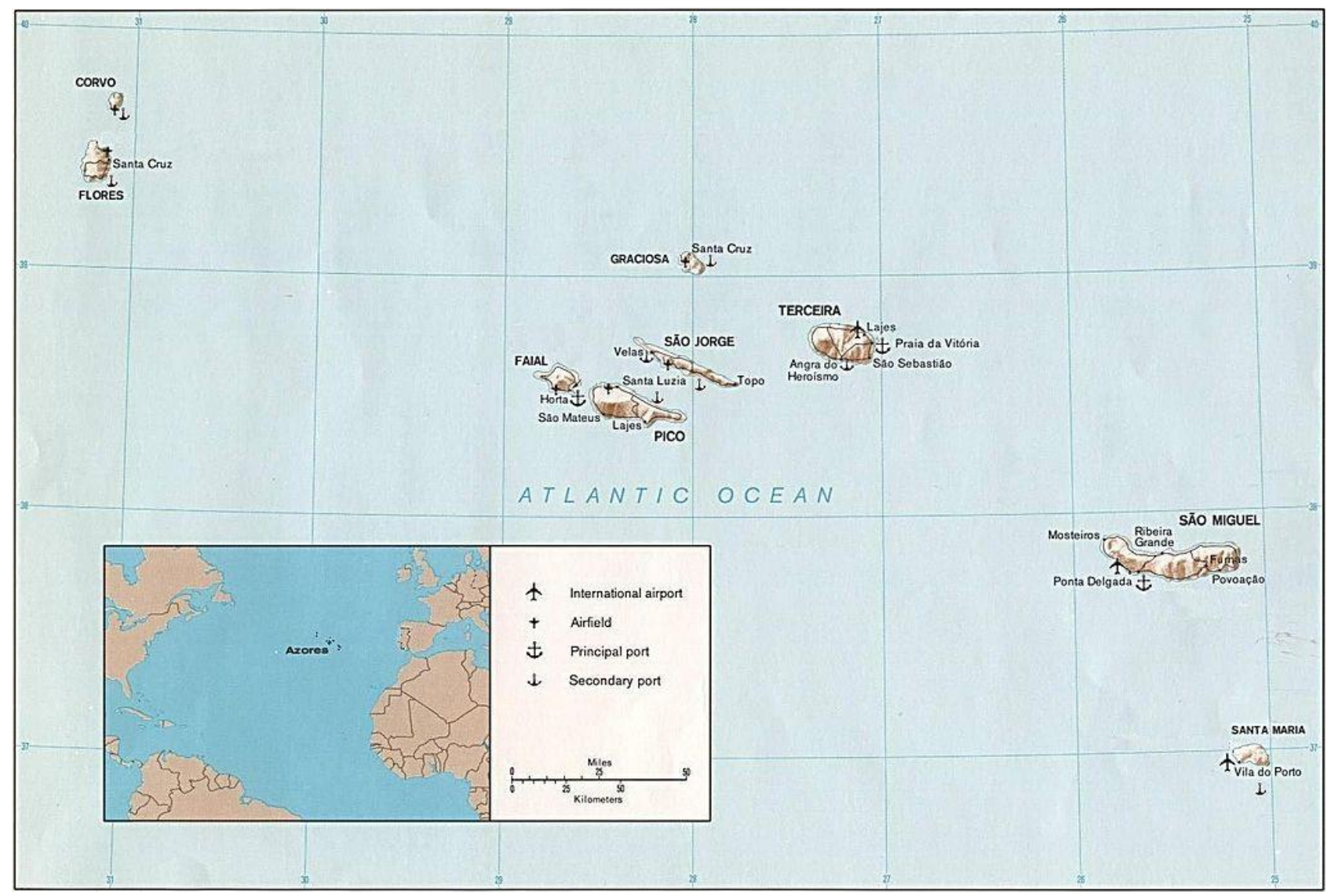

Figure 1. Azores Archipelago location (28). 
which registers a variation in population density in 230 inhabitants per $\mathrm{km}^{2}$.

Generally, the Azores' landscape is marked by a strong orography, where the high altitude is associated with the hardy relief. The islands emerge sharply from the ocean, showing significant vertical growth. The mountainous interior is furrowed by deep ravines, which tear the slopes down to sea level. The flat areas are poorly developed, with little representation in the island territory, emphasizing the west side of Santa Maria, Ponta Delgada, and graben of Ribeira Grande in São Miguel and graben of Praia da Vitória in Terceira. The plateau regions can be summed up in the Central Plateau in Flores, in the Achada Plateau in Pico, and the Graminhais and Furnas Achada Plateaus in the western half of São Miguel. The different islands' maximum altitude ranges between $405 \mathrm{~m}$ in Graciosa and 2,351 $\mathrm{m}$ in Pico, the highest point in Portugal. The islands' landscape is usually overwhelmed by the magnificent lagoons that occupy the abatement craters of extinct volcanoes (29).

In the Azores, the production systems represent the primary income and employment generation's primary sources, reflecting the endogenous economic support capacity. The emphasis is placed on the incidence and evolution of the agricultural and agri-food sector, the installed trends and prospects for qualification and diversification of the tourist sector, and extractive activities associated with civil construction (29).

In this region, the urban and rural systems represent the patterns and dynamics of urban occupation and rural settlement. Urban and rural settlement dynamics stand out in this context, and the location, shape, and structure of urban agglomerations in harmony with urban expansion and housing dynamics. Moreover, it is possible to verify a tendency of slight population growth, the persistence of a high index of rurality in the population's residence, and average values in Portugal (29).

Moreover, this Archipelago shows a significant increase in urban areas in evolutionary terms, reflecting the urban growth that has been witnessing in recent years. The agricultural and pasture areas have decreased in recent years, considering that in the 90's they represented more than $50 \%$ of the Azores area. Contrarily, there was an increase in forest areas and natural environments, when in the middle of the 90's decade, they represented near $30 \%$ of the Azores' territory.

Accessibility and equipment systems are part of the infrastructure, transport, communications, energy, and collective equipment networks (30). So, we should highlight the need to provide a set of services (utilities, communications, and energy) and mobility conditions to populations, tourists, and economic agents, as a privileged instrument of cohesion and competitiveness policies. Moreover, all islands have one or more port infrastructures representing on average $0.06 \%$ of each island's surface area.

\section{MATERIAL AND METHODS}

Considering the study's objective, several approaches and techniques were used, including direct and indirect analysis methods.

The methodological procedure was divided into four main stages: elaboration of the questionnaires, data collection, analysis of the case study, and interpretation of the results ending with the discussion and conclusions (Figure 2). The last phase focuses on the impact of an infectious disease influence on the development of an ultra-peripheral region as the Azores. In this regard, some guidelines and recommendations are provided to the actors and decisionmakers related to planning and regional development.

Accordingly, the Azores Archipelago was used as a case study. Studies on similar themes, previously carried out by the team (31-36), provided a prior knowledge of the regional reality, allowing the collection of a more robust quantity and quality of data. In this way, on the one hand, the authors have precisely understood the fundamental issues regarding how this health crisis influences the regional development of an insular region. On the other hand, it also led to an understanding of how this crisis affects local entrepreneurs and consequently the region's sustainable development and planning.

The study was approved by the Ethics Committee of Azores University (Comissão de Ética of Universidade dos Açores, 18/2021, UAC/2021/4700).

\section{Questionnaires and Sampling}

The questionnaires were planned, recognizing the necessity to carry out online interviews. This typology of the questionnaire was selected considering the social distancing necessities caused by the SARS-CoV-2 pandemic.

This study sample was formed of 700 participants, and the web-surveys were carried out in the Spring months of 2020. In this research, most of the respondents were female, and the most representational age group was 35-54 years old. More than $60 \%$ of respondents were married. The participants' most representative educational training was university education, and the least representative was basic education. Moreover, more than $50 \%$ of the study participants were residents of the Azores Eastern Group, more precisely from São Miguel Island.

\section{Statistical Analysis}

After the data from the surveys were gathered, analytical methods and tools were used. Firstly, we used spreadsheets to compile data, which was then statistically explained using IBM SPSS Statistics (Statistical Package for the Social Sciences).

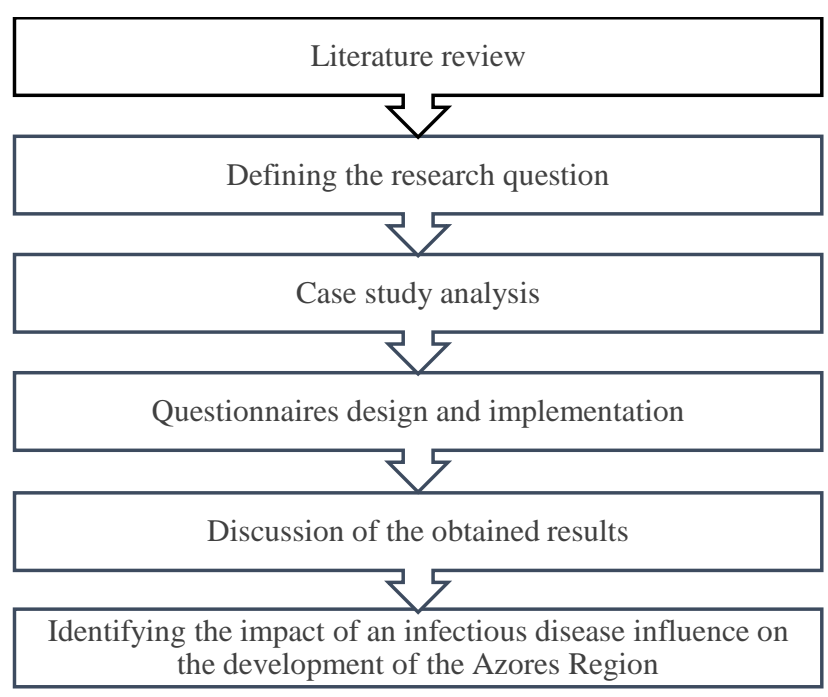

Figure 2. Methodological scheme 


\section{RESULTS}

This section describes the obtained results through the use of exploratory tools applied to the case study.

Contextually, a question was made about the typology of accommodation for the 2020 vacation. Recognizing that we used open and short questions, 10 options were created due to many responses (Table 1). The most frequently selected option was to spend the 2020 vacation at family or friends' holiday residence (more than $20 \%$ ), followed by those who opted for three to four-star hotels. There was a considerable increase in selecting rural tourism accommodations, reaching the third position with more than $13 \%$, followed by pensions with $12.1 \%$. A similar percentage was identified between the number of participants who wish to rent an apartment or residence (more than 9\%) and the respondents who want their own holiday residence $(8.8 \%)$ to spend the 2020 vacation. The same values were verified for camping and/or cruise options and five-star hotels. About hotels with less than three stars, the obtained values were low (2.1\%). Additionally, less than $1 \%$ of the respondents stated that they had not yet decided on the type of accommodation for the 2020 vacation.

A question was also asked regarding the type of holiday accommodation (Table 2), with three options: (i) tourist accommodation in rural areas; (ii) tourist accommodation in an urban environment with green spaces; and (iii) tourist accommodation in an urban environment without green spaces. Although the results obtained show similar values, the most selected option was tourist accommodation in an urban environment with green spaces (ii), with $47.8 \%$ of the responses, followed by tourist accommodation in rural areas (i) with $43.8 \%$. The least selected option was tourist accommodation in an urban environment without green spaces (iii), with less than $10 \%$.

Among the participants who selected at least one of the answer options shown in Table 3, more than half considered that the "Clean and Safe" stamp (attributed by the Portuguese Health Authorities) is crucial when choosing accommodation and restaurants $(75.8 \%)$ as well as for choosing the destination to visit (50.5\%). Consequently, the results suggest that efforts should be made to grant this stamp to the regional touristic establishments.

Through the categorical analysis of principal components (PCA) in the data submatrix that contains items A.1 to A.6 and B.1 to B.6, five principal components were extracted using varimax rotation with Kaiser normalization, which explains about $70 \%(22.6 \%, 13.2 \%, 12.6 \%, 11.3 \%$, and $9.9 \%$ ) of the data variance (Table 4).

The items mostly related to the first principal component are items A.3, A.4, A.5, and A.6, so this dimension was called "social isolation." The second dimension's most essential items are items B.4, B.5, and B.6, which is why this component was called "search for cheaper travel options". Items A.1 and A.2 are the items that most contribute to the explanation of component three, which is why it was called "security." The items most related to dimension four are items B.2 and B.3; therefore, this was called "repercussions of SARS-CoV-2 at the level of holidays". Finally, the fifth main component was called "vacation expenses, compared to 2019" because item B.1 is the essential item for this dimension.
Table 1. Grouped options associated with the typology of accommodation for the 2020 vacation

\begin{tabular}{lc}
\hline Options & \% \\
\hline Not decided yet & 0.8 \\
In my vacation residence & 8.8 \\
Apartment or rented house & 9.5 \\
Camping or cruise & 4.3 \\
Family or friends vacation residence & 24.3 \\
Pension & 12.1 \\
Less than three star hotel & 2.1 \\
Three to four star hotel & 20.1 \\
Five star hotel & 4.3 \\
Rural tourism & 13.7 \\
\hline
\end{tabular}

Table 2. Closed-up question regarding the accommodation selection options

\begin{tabular}{lcc}
\hline Options & n & \% \\
\hline i. Tourist accommodation in rural areas & 272 & 43.8 \\
ii. Tourist accommodation in an urban & 297 & 47.8 \\
environment with green spaces & & \\
iii. Tourist accommodation in an urban & 52 & 8.4 \\
environment without green spaces & 621 & 100.0 \\
Total & 83 & \\
Missing & 704 & \\
Total & & \\
\hline
\end{tabular}

Table 3. Closed-up question regarding the stamp "Clean and Safe"

\begin{tabular}{lcc}
\hline Options & n & $\%$ \\
\hline When choosing accommodation and restaurants & 470 & 75.8 \\
When choosing touristic activities & 173 & 27.9 \\
When choosing the destination to visit & 313 & 50.5 \\
\hline
\end{tabular}

Table 4. Factorial matrix - after using the varimax method

\begin{tabular}{cccccc}
\hline \multicolumn{5}{c}{ Components } \\
\hline & $\mathbf{1}$ & $\mathbf{2}$ & $\mathbf{3}$ & $\mathbf{4}$ & $\mathbf{5}$ \\
\hline A.1 & 0.065 & 0.055 & 0.839 & 0.093 & -0.103 \\
A.2 & 0.066 & 0.023 & 0.847 & -0.029 & 0.177 \\
A.3 & 0.864 & 0.068 & 0.099 & 0.083 & -0.140 \\
A.4 & 0.883 & 0.062 & 0.100 & 0.082 & -0.057 \\
A.5 & 0.811 & 0.035 & 0.125 & 0.062 & 0.024 \\
A.6 & 0.631 & 0.135 & -0.198 & 0.050 & 0.253 \\
B.1 & 0.013 & 0.030 & 0.073 & 0.028 & 0.877 \\
B.2 & 0.087 & -0.052 & 0.030 & 0.838 & 0.255 \\
B.3 & 0.091 & 0.230 & 0.052 & 0.683 & -0.428 \\
B.4 & 0.129 & 0.795 & -0.022 & -0.038 & 0.109 \\
B.5 & -0.014 & 0.812 & 0.090 & 0.090 & -0.050 \\
B.6 & 0.298 & 0.459 & 0.024 & 0.384 & -0.180 \\
\hline
\end{tabular}




\section{DISCUSSION AND CONCLUSIONS}

In the current pandemic context, we are witnessing an abrupt decline in economic activity. Consumption decreased due to quarantines (lockdowns) and the decrease in the population's income. Production decelerated due to the drop in demand, the retention of workers at home and/or teleworking options, and the scarcity of intermediate and investment goods.

In this context, companies and individuals' financial situation is degraded, especially in the sectors most exposed to the health crisis's direct consequences, as is the case of the tourism sector.

The health crisis's economic consequence will considerably depend on the responses made at several levels: individual behavior, companies and workers, national governments, and international entities.

Contextually, tourism is one of the most dynamic economic activities and has the most significant growth potential globally (37-40). The tourism sector is increasingly recognized for the vast benefits it represents for countries, mostly for emerging economies, given its ability to promote and strengthen international relations to generate foreign exchange, create jobs, and potentially serve as a catalyst for regional development (39-41). According to the World Travel and Tourism Council (42), it is estimated that the sector contributes $10 \%$ of the world GDP (Gross Domestic Product). In fact, tourism-related activity generates one in ten jobs, and its turnover is comparable to or greater than that of other vital sectors. I.e., exports of oil, food products, or automobiles are just a few examples.

On the other hand, tourists' intentions show significant dynamics, both in terms of destination choice and accommodation selection (43-47). After the outbreak of infectious disease, as is the case with the SARS-CoV-2, the dynamics change to an unprecedented level. In fact, these premises were confirmed, once more, by the present research.

The "COVID-19 Free" or "Clean and Safe" stamp attributed by the Portuguese Health Authorities to tourist accommodation was the item with the survey participants' greatest agreement. On the other hand, the lowest level of agreement was related to the item "I will avoid air travel in the future," reflecting that people do not intend to stop traveling. There is some confidence on the part of the respondents about the current situation of the SARS-CoV-2 crisis.

Around $42.3 \%$ of respondents showed that they were willing to pay more for safe holidays. The security dimension is vital today in this sector. The "Clean and Safe" stamp is essential when choosing accommodation, restaurants, as well as the destination to visit. Consequently, the obtained results suggest that efforts should be made in this regard. Thereby, the study allows us to conclude that there are huge repercussions for SARSCoV-2 regarding vacation options and social isolation issues and consequently over the regional development of territory with the socio-economic strictly linked with the tourism sector.

Although, and studying the thematic literature, more specifically the investigations carried out by Faulkner and Vikulov (48), a crisis can lead to a specific change in the tourism of a destination, which should not necessarily be understood as a negative impact. Besides, several other critical studies that have analyzed similar phenomena should also be respected for understanding this specific issue (49-53). Thus, the main regional actors and decisionmakers must use the current moment to envision and consequently plan a more sustainable future for the Azores' territory.

So, considering the horizontal impacts of this pandemic crisis, the response should be also be based on a multidisciplinary perspective. Thereby, only through a multi-varieted strategy, where several fields and solutions were crossed and combined, will it be possible to mitigate and overcome the SARS-CoV-2 crisis impacts in the longterm.

Study Limitations and Prospective Research Lines

Although this investigation broadens our understanding of how the impacts of the SARS-CoV-2 outbreak influenced the development of an ultra-peripheral region as the Azores, research lines remain relevant. In fact, this study focuses only on the initial period of the virus outbreak, precisely the period between May and June 2020.

Therefore, considering that the pandemic crisis presents a considerably longer time window than the period analyzed by the present investigation, similar studies should be carried out about this study's precursor and predecessor months.

Although the present study provides interesting perspectives on the impacts over the development of an ultra-peripheral region as the Azores Archipelago, if further investigations were conducted on island territories, complementary results would be obtained to understand the problem from a global perspective.

Ethics Committee Approval: The study was approved by the Ethics Committee of Azores University (Comissão de Ética of Universidade dos Açores, 18/2021, UAC/2021/4700).

Conflict of Interest: None declared by the authors.

Financial Disclosure: FCT_Fundação para a Ciência e a Tecnologia, I.P., project number UIDB/00685/2020.

Acknowledgements: This paper is financed by Portuguese national funds through FCT — Fundação para a Ciência e a Tecnologia, I.P., project number UIDB/00685/2020 and also by the project GREATGenuine Rural Experiences in the Azores Tourism with the code: ACORES-01-0145-FEDER-000089.

Author Contributions: Idea/Concept: RAC, GC, PP, AS, CC, MGB; Design: RAC, GC, PP, AS, CC, MGB; Data Collection/Processing: RAC, GC, PP, AS, CC, MGB; Analysis/Interpretation: RAC, GC, PP, AS, CC, MGB; Literature Review: RAC, GC, PP, AS, CC, MGB; Drafting/Writing: RAC, GC, PP, AS, CC, MGB; Critical Review: RAC, GC, PP, AS, CC, MGB.

All the authors contributed equally to the development of the present paper. All phases of the paper development have been proper discussed and worked on by the authors. All authors have read and agreed to the published version of the manuscript. 


\section{REFERENCES}

1. Mora Aliseda J. El coronavirus obliga a una respuesta sin fronteras. Special Issue of: Reflexiones sobre el coronavirus y sus impactos in Revista Científica Monfragüe Resiliente-Scientific Journal. 2020;(Special Issue):6-8.

2. Gössling S, Scott D, Hall CM. Pandemics, tourism and global change: a rapid assessment of COVID-19. J Sustain Tour. 2020;29(1):1-20.

3. Tatem AJ, Rogers DJ, Hay SI. Global transport networks and infectious disease spread. Adv Parasitol. 2006;62:293-343.

4. Wilson ME. Global travel and emerging infections. In: Choffnes ER, Mack A, Relman DA, editors. Infectious diseases movement in a borderless world, workshop summary. Washington, DC: The National Academies Press; 2010. p.90-104.

5. Browne A, Ahmad SS, Beck CR, Nguyen-Van-Tam JS. The roles of transportation and transportation hubs in the propagation of influenza and coronaviruses: a systematic review. J Travel Med. 2016;23(1):tav002

6. Burkle Jr FM. Globalization and disasters: issues of public health, state capacity and political action. Journal of International Affairs. 2006;59(2):241-65.

7. Gössling S. Global environmental consequences of tourism. Glob Environ Change. 2002;12(4):283-302.

8. Hall CM. Tourism urbanization and global environmental change. In: Gössling S, Hall CM, editors. Tourism and global environmental change: Ecological, economic, social and political interrelationships. London: Routledge; 2006. p.142-56.

9. Page S, Yeoman I. How VisitScotland prepared for a flu pandemic. Journal of Business Continuity \& Emergency Planning. 2007;1(2):167-82.

10. Fauci AS, Morens DM. The perpetual challenge of infectious diseases. N Engl J Med. 2012;366(5):454-61.

11. Scott D, Gössling S. What could the next 40 years hold for global tourism? Tourism Recreation Research. 2015;40(3):269-85.

12. Qureshi AI. Economic and political impact of ebola virus disease. Ebola Virus Disease. 2016;177-91.

13. Rosselló J, Santana-Gallego M, Awan W. Infectious disease risk and international tourism demand. Health Policy Plan. 2017;32(4):538-48.

14. Abukhalifeh A, Faller EM, Ahmad A, Tadros S. Current issue in tourism: Diseases transformation as a potential risks for travellers. Glob Stoch Anal, 2018;5(7):341-50.

15. Qiu W, Chu C, Mao A, Wu J. The impacts on health, society, and economy of SARS and H7N9 outbreaks in China: A case comparison study. J Environ Public Health. 2018;2018:2710185.

16. Bloom DE, Cadarette D. Infectious disease threats in the twenty-first century: Strengthening the global response. Front Immunol. 2019;10:549.

17. Espinoza D. La Propuesta de Trabajo de Costa Rica para Atender en la Crisis Pandémica por el SARS-COV-2 y la Participación de las Universidades Estatales. Special Issue of: Reflexiones sobre el coronavirus y sus impactos in Revista Científica Monfragüe ResilienteScientific Journal. 2020;(Special Issue):66-80.

18. Castanho RA. A pandemic crisis shocking us all: The COVID-19. Special Issue of: Reflexiones sobre el coronavirus y sus impactos in Revista Científica Monfragüe Resiliente-Scientific Journal. 2020;(Special Issue):233-8.

19. Abu Bakar N, Rosbi S. Effect of coronavirus disease (COVID-19) to tourism industry. International Journal of Advanced Engineering Research and Science. 2020;7(4):189-93.

20. McKibbin W, Roshen F. The economic impact of COVID-19. In: Baldwin R, di Mauro BW, editors. Economics in the time of COVID-19. London, UK: CEPR Press; 2020. p.45-52.

21. oecd.org [Internet]. Organisation for Economic Cooperation and Development. The impact of the coronavirus (COVID-19) crisis on development finance. [Cited: 2020, Jul 21]. Available from: https://read.oecd-ilibrary.org/view/?ref=134_134569xn1go1i113\&title=The-impact-of-the-coronavirus(COVID-19)-crisis-on-development-finance

22. Ranasinghe R, Damunupola A, Wijesundara S, Karunarathna C, Nawarathna D, Gamage S, et al. Tourism after corona: Impacts of COVID-19 pandemic and way forward for tourism, hotel and mice industry in Sri Lanka. Hotel and Mice Industry in Sri Lanka. SSRN. 2020. doi: 10.2139/ssrn.3587170.

23. Sigala M. Tourism and COVID-19: impacts and implications for advancing and resetting industry and research. Journal of Business Research. 2020;117:312-21.

24. unctad.org [Internet]. United Nations Conference on Trade and Development. COVID-19 and tourism: Assessing the economic consequences. [Cited: 2020, Aug 31]. Available from: https://unctad.org/system/ files/official-document/ditcinf2020d3_en.pdf.

25. Castanho RA, Lousada S, Camacho R, Naranjo Gómez JM, Loures L, Cabezas J. Ordenamento territorial e a sua relação com o turismo regional. O caso de estudo da Região Autónoma da Madeira (RAM). Cidades. Comunidades e Territórios. 2018;36:42-55.

26. Santos R, Castanho RA, Lousada S. Return migration and tourism sustainability in Portugal: Extracting opportunities for sustainable common planning in Southern Europe. Sustainability. 2019:11(22):6468.

27. Naranjo Gómez JM, Lousada S, Velarde JG, Castanho RA, Loures L. Land-use changes in the canary archipelago using the CORINE data: A retrospective analysis. Land. 2020;9(7):232.

28. Reliefweb.int [Internet]. ReliefWeb. Reference map of Azores Islands. [Cited: 2020, Nov 30]. Available from: https://reliefweb.int/map/azores-islandsportugal/reference-map-azores-islands

29. COS.A. Carta de Ocupação do Solo da Região Autónoma dos Açores. Direção Regional do Ambiente e Inforgeo. Horta, Faial, Açores, Portugal. Relatorio_COS.A_2018.pdf (azores.gov.pt). (In Portuguese), 2018.

30. Castanho RA, Naranjo Gómez JM, Vulevic A, Behradfar A, Couto G. Assessing transportation patterns in the Azores Archipelago. Infrastructures. 2021;6(1):10.

31. Vieira J, Couto G, Pimentel P, Menezes A, Moniz A, Sousa F. The satisfaction of the Nordic Tourist with the Azores as a destination. Scandinavian Journal of Hospitality and Tourism. 2013;13(sup1):58-72.

32. Couto G, Pimentel P, Ponte J. Tourism development potential in an insular territory: the case of Ribeira 
Grande in the Azores. J Tourism Res Hospitality. 2017;6(2). doi: 10.4172/2324-8807.1000166

33. Castanho RA, Couto G, Pimentel P. Principles of sustainable tourism and cultural management in rural and ultra-peripheral territories: Extracting guidelines for application in the Azores Archipelago. Cult Manag Sci Educ. 2020;4(1):9-24.

34. Couto G, Castanho RA, Pimentel P, Carvalho C, Sousa Á, Santos C. The impacts of COVID-19 crisis over the tourism expectations of the Azores archipelago residents. Sustainability. 2020;12(18):7612.

35. Castanho RA, Couto G, Pimentel P, Carvalho CB, Sousa Á. Territorial management and governance, regional public policies and their relationship with tourism. A case study of the Azores autonomous region. Sustainability. 2020;12(15):6059.

36. Castanho RA, Couto G, Pimentel P, Carvalho C, Sousa Á, Velarde JG. Assessing the impacts of public policies over tourism in Azores Islands. A research based on tourists and residents perceptions. WSEAS Transactions on Environment and Development. 2020;16:744-53.

37. Labrianidis L, Ferrão J, Hertzina K, Kalantaridis C, Piasecki B, Smallbone D. The Future of Europe's Rural Periphery; Final Report; 5th Framework Programme of the European Community, 2003.

38. Sharpley R, Vass A. Tourism, farming and diversification: An attitudinal study. Tourism Management. 2006;27(5):1040-52.

39. Chen KH, Yang HY. Appraising the economic impact of the "opening up to mainland Chinese tourist arrivals" policy on Taiwan with a tourism-CGE model. Asia Pacific Journal of Tourism Research. 2010;15(2):155-75.

40. Santos R. O regresso dos emigrantes portugueses e o desenvolvimento do turismo em Portugal (Doctoral dissertation, Tese de Doutoramento, Departamento de Economia, Gestão, Engenharia Industrial e Turismo, Universidade de Aveiro), 2003.

41. Fernández-Jeri A. El Comportamiento del Consumidor Convencional de Alimentos Durante el COVID-19, en el Perú. Special Issue of: Reflexiones sobre el coronavirus y sus impactos in Revista Científica Monfragüe Resiliente-Scientific Journal, 2020;(Special Issue):86-92.

42.wttc.org [Internet]. World Travel and Tourism Council. Economic Impact Reports. [Cited: 2020, Jul
21]. Available from: https://wttc.org/Research/ Economic-Impact

43. Oppermann M. Tourism destination loyalty. Journal of Travel Research. 2000;39(1):78-84.

44. Yavas U, Babakus E. Dimensions of hotel choice criteria: congruence between business and leisure travelers. International Journal of Hospitality Management. 2005;24(3):359-67.

45. Bigné JE, Mattila AS, Andreu L. The impact of experiential consumption cognitions and emotions on behavioral intentions. Journal of Services Marketing. 2008;22(4):303-15.

46. Chin CH, Law FY, Lo MC, Ramayah T. The impact of accessibility quality and accommodation quality on tourists' satisfaction and revisit intention to rural tourism destination in Sarawak: the moderating role of local communities' attitude. Global Business and Management Research. 2018;10(2):115-27.

47. Aruan DTH, Felicia F. Factors influencing travelers' behavioral intentions to use $\mathrm{P} 2 \mathrm{P}$ accommodation based on trading activity: Airbnb vs Couchsurfing. International Journal of Culture, Tourism and Hospitality Research. 2019;13(4):487-504.

48. Faulkner B, Vikulov S. Katherine, washed out one day, back on track the next: a post-mortem of a tourism disaster. Tourism Management. 2001;22(4):331-44.

49. Wen J, Kozak M, Yang S, Liu F. COVID-19: potential effects on Chinese citizens' lifestyle and travel. Tourism Review. 2020;76(1):74-87.

50. Melly D, Hanrahan J. Tourism biosecurity risk management and planning: an international comparative analysis and implications for Ireland. Tourism Review. 2020;76(1):88-102.

51. Dai YD, Zhuang WL, Lu SC, Huan TC. Work engagement or job burnout? Psychological ownership amongst the employees of international tourist hotels. Tourism Review. 2020; [Epub ahead of print]. doi: 10.1108/tr-03-2020-0087.

52. Boğan E, Dedeoğlu BB, Dedeoğlu SB. The effect of residents' perception of hotel social responsibility on overall attitude toward tourism. Tourism Review. 2020; [Epub ahead of print]. 10.1108/TR-08-20190353.

53. Fakfare P, Wattanacharoensil W. Impacts of community market development on the residents' wellbeing and satisfaction. Tourism Review. 2020;[Epub ahead of print]. doi: 10.1108/tr-02-2020-0071. 